\title{
ARTICLE DO UNDERGRADUATE JOURNALISM STUDENTS TEND TO WRITE REPORT- BOOKS ON HUMAN RIGHTS?
}

Copyright (๔) 2017 SBPjor / Associação Brasileira de Pesquisadores em Jornalismo

\section{MARCOS ANTÔNIO ZIBORDI}

Research Group on Epistemology and Social Dialogue, Universidade de São Paulo, São Paulo - SP, Brazil

ORCID: 0000-0003-4818-2117

DOI: http://dx.doi.org/10.25200/BJR.v13n3.2017.994

The objective of this article is to present updated results of incipient research on report-book production (Lima, 2009) by journalism undergraduate students. We relate three data sets to support the premise that these authors tend to focus on humanitarian topics, regardless of the Brazilian region and the course type, public or private. A private educational institution in the city of São Paulo is being systematically researched and in this article we publish results between 2015 and 2017 regarding the journalistic products made by the undergraduate students, mainly report-books. This information is intersected with the winning works of two national awards, the Brazilian Association of Investigative Journalism (Abraji) and the Experimental Research in Communication Exhibition (Expocom), whose journalistic products and selected topics in annual competitions adopt the same perspective of those produced in the researched institution of São Paulo, indicating that, for the time being, at least the hypothesis of this research is justified.

Key words: Journalism; Report book; Narrative; Abraji; Expocom.

\section{GRADUANDOS EM JORNALISMO TENDEM A ESCREVER LIVROS-REPORTAGEM SOBRE DIREITOS HUMANOS?}

RESUMO - O objetivo deste artigo é apresentar resultados atualizados de incipiente pesquisa sobre produção de livros-reportagem (Lima, 2009) por graduandos de Jornalismo. Relacionamos três conjuntos de dados para sustentar a premissa de que esses autores tendem a pautar temas humanitários, independente da região do Brasil e do tipo de curso, público ou particular. Uma instituição de ensino privada da capital paulista está sendo sistematicamente pesquisada e neste artigo publicamos resultados entre 2015 e 2017 referentes aos produtos jornalísticos realizados pelos concluintes, sobretudo livros-reportagem. Essas informações são cruzadas com os trabalhos vencedores de duas premiações nacionais, a da Associação Brasileira de Jornalismo Investigativo (Abraji) e a da Exposição de Pesquisa Experimental em Comunicação (Expocom), cujos produtos jornalísticos e temas selecionados em certames anuais adotam a mesma perspectiva daqueles produzidos na instituição paulistana pesquisada, 
DO UNDERGRADUATE JOURNALISM STUDENTS TEND TO WRITE REPOKT-BOOKS ON HUMAN RIGHTS?

indicando que, por enquanto, pelo menos a hipótese desta pesquisa se justifica.

Palavras-chave: Jornalismo; Livro-reportagem; Narrativa; Abraji; Expocom.

\title{
GRADUANDOS EN PERIODISMO TENDEN A ESCRIBIR LIBROS-REPORTAGEN SOBRE DERECHOS HUMANOS?
}

\begin{abstract}
RESUMEN - RESUMEN - El objetivo de este trabajo es presentar los resultados actualizados de la investigación incipiente en la producción de libros-reportaje (Lima, 2009) de los estudiantes universitarios de periodismo. Tenemos una lista de tres conjuntos de datos para apoyar la premisa de que estos autores tienden a basarse cuestiones humanitarias, con independencia de la región y el tipo de curso, pública o privada. Una institución educativa privada de la capital del estado se está investigando y este artículo publicado resultados entre 2015 y 2017 en relación con productos periodísticos realizados por los graduados, especialmente los libros-reportaje. Esta información es una referencia cruzada con los ganadores de dos premios nacionales, la Asociación Brasileña de Periodismo Investigativo (Abraji) y la Exposición de Investigación Experimental en Comunicación (Expocom), cuyos productos y temas seleccionados periodística en concursos anuales adoptan la misma perspectiva de producido en la institución de Sao Paulo investigado, lo que indica que, al menos por ahora la hipótesis de esta investigación se justifica.

Palabras clave: Periodismo; Libro-informe; Narrativa; Abraji; Expocom.
\end{abstract}

\section{A difficult question to answer}

This is the second article we have written to update incipient research on report-books. The specific clipping is the training of journalists ${ }^{1}$ and here we compare the results of national competitions for undergraduate report-book authors with the production of the same formats in a private University Center with an expressive number of Journalism students in the capital of São Paulo, about 1,300 enrolled in the first semester of 2017, the largest contingent of this course in the city ${ }^{2}$.

We want to explore the following: is there a tendency for humanitarian assignments when undergraduate students choose to write a report-book? In other words, do they perceive several marginalized types as social protagonists?

These questions, whose scientific and pedagogical interest seem obvious to us, run the risk of never being answered to the satisfaction because there are limits that even the least ambitious quantitative method may not surpass already in this initial research phase, in which we begin to collect basic data, such as quantity, 
topic and types of work accomplished at the Journalism Brazilian courses' conclusion. However, we understand that such difficulties justify even more the need to know better, which formats and topics undergraduate students choose for their final works, this article being part of the effort related to the report-book.

Because it is one of the first articles of this research that we consider being unpublished or, at least, embryonic, we consider it important to begin by discussing the methodological difficulties of indexing. The first obstacle to the researcher is the widespread disregard for undergraduate productions, not always cataloged in virtual libraries, even less available for material consultation. In field, we verified that when research reports are on the shelves, the resulting products, especially books, almost never are. In a world in which scientific productions are easily found via internet, the researcher interested in trained journalists, the possible way to capture information is still handmade: it presupposes contacting each course coordinator by e-mail, telephone and in person. That is why, so far, we envisage the possibility of, at most, making indicative and punctual surveys, uncertain in their scope.

This is because even when it is possible to obtain data on journalistic products developed in courses with a great numbers of students, as in this article, numerical greatness is limited to a city or part of it, as it tends to occur in the state capital, where social differences are conspicuous depending on where the researched institution is located, especially when we include the surrounding cities.

Another punctual data limitation does not refer only to the fact that it is always a context clipping, even if, alone, it figures as numerically expressive. The challenge of forming minimal historical series, even from the same educational institution, is enormous. These data organization often depends on the personal commitment of overloaded coordinators and assistants in high turnover jobs.

The researcher interested in training journalists will constantly deal with fragmentary information and should activate the methodological imagination to build minimally reliable databases. More ambitious surveys, such as national panoramas, will only be possible in the context of integrated projects involving researchers from different levels, from the scientific initiation to the postgraduate level, given the amount of work and time required, since "accuracy has a cost, proportional to the operation's scale and complexity; and this cost is prohibitive" (Besson 1995: 28). 
In this sense, this research, whose results up to 2017 are presented in this article, is reportedly an incentive for future comprehensive mappings, achievable by as many scientists as possible. To us, it is incomprehensible that neither the labor market nor educational or governmental institutions have great interest in undergraduate productions, from the point of view of the chosen formats (radio, audiovisual, virtual, printed and monographs), as well as from the topics (social, cultural, economic, political, sports) point of view.

Calling for comprehensive mappings may indicate reliable trends. In order to use two theoretical expressions also used by Edvaldo Pereira Lima (2009) when defining report-book, the research procedure in relation to Journalism undergraduate students' productions should be horizontal and vertical, in other words, to raise types and topics, if possible nationally, or by large regions, and to verticalize the approach with the least temporal perspective, since journalistic products developed in public and private institutions resonate changing professional trends regarding language, such as the current fury with fashion blogs, the perspectives offered by the job market, such as the irreversible content virtualization, direct influences of teachers linked to this or that information format and even cultural continuities, such as in the capital of São Paulo, where the production of report-books by Journalism undergraduate students seems to be initially linked to the University of São Paulo (USP), where researchers such as Cremilda Medin still act.

From 1987 onwards, she organized the report-book series São Paulo de perfil, with 27 editions on the metropolis' topics (Medina, 1994). The narratives recorded in these books mainly focused on the outskirts, and according to Santana's cartography (2009, p. 142), the work dealt with locations such as Engenheiro Marsilac at the extreme south, to Vila Nova Galvão, at the northern boundary, up to Vila Pernambuco, at the end of the East side.

The work of another USP professor, Edvaldo Pereira Lima, also has a strong impact on the training of several professionals. His doctoral thesis, defended in 1990 and published in the book Páginas Ampliadas: o livro-reportagem como extensão do jornalismo $e$ da literatura (Extended Pages: the report-book as an extension of journalism and literature), with several reprints, is a reference, being used in this article the version that deserved further expansion and update, 2009. Lima Founded the Brazilian Academy of Literary Journalism, which offers postgraduate courses since 2005. 
If there are possible continuities between the theoretical production and the practice of report-books in the Journalism courses of São Paulo's capital, we again point out the need for mappings that cannot be restricted to educational institutions, as we have researched. Considering this need for more complex expansion and perception, we cross data of the private institution of São Paulo with two national awards for journalism undergraduate students' report-books, trying to perceive the work trajectory that manage to extrapolate the scope of their own course and institution, deserving professional representative associations' and researchers' distinction.

However, we inevitably face other methodological problems by including, in this research, the awards of the Brazilian Association of Investigative Journalism (Abraji) and the Experimental Research in Communication Exhibition (Expocom). They annually reward work considered relevant and this clipping, in spite of sifting the (considered) best productions, again erases context, since the disqualified work and, even more, those that did not compete, are part of the total of the Journalism undergraduate students' production in Brazil. Just as in literature, distortions occur due to the privilege of a certain canon, when we choose journalistic work in book we leave behind others whose topics and other aspects may be very different from the tendency indicated by the awardees of Abraji and Expocom.

To point out obstacles that, in the limit, could impede this research, is equivalent to the critical alert on quantitative procedures. We do not do odes to Cartesianism, to Positivism, nor to access and production databases growing possibilities (Medina, 2008; Thiollent, 1987). There are innumerable problems, usually concealed, in constructing opinion from data collected from third parties, such as the questionnaire application that respondents interpret in different ways, with diverse interests and attention levels, lists of rigidly structured issues, but in fact very malleable, although they do not seem so, as well as we cannot disregard the complexity of the incidence related to the questionnaire application place, to the inclusion criteria and answer rejection, to the possibility of implicitly directing them with questions, such as in electoral polls among other inherent subjectivities that "can vary both in its intensity and in its expression, according to the circumstances, places, parties or situations" (Besson, 1995, p. 225).

The alleged truth of numbers misleads; therefore, in relation to the data on the production of report-books of the University Center 
of São Paulo presented in the next topic and indicative of significant production privileging humanitarian issues, it is necessary to clarify hasty generalizations with the information that the majority of the students are not economically privileged. Therefore, the tendency towards such topics may be related to the student's trajectory and may not be the same in courses with a different socio-economic profile, despite the fact that the national awards for journalism undergraduate students' report-book reinforce the humanitarian thematic trend in public and private institution work, of several regions of Brazil (we will use expressions such as "humanitarian" and "humanized" in this article, but the precise meaning refers to the rights guaranteed in the National Human Rights Plan, in its third version in Brazil, as we will be explained in later theoretical section).

Faced with many possible limitations, why undertake this research? Firstly, the proposal intends to call attention to the scientific and practical relevance of journalistic products developed by undergraduate students as Course Completion Work (TCCs). From an epistemological point of view, this means that we do not share values whose matrices were announced 380 years ago in René Descartes's Discourse on the Method (2001). Thinking along with another Frenchman, Edgar Morin, prejudiced hierarchies between undergraduate and graduate productions are the fruit of the "simplification paradigm" that operates by destroying "sets and totalities" and isolating "all objects from what surrounds them" (Morin, 2010, p.18).

In addition to the relevance of the report-books' production, this research seeks to advance, including as methodological learning, to the possible limits of obtaining information about the long journalistic narratives in book and its issues, because only then we can know the measure of incompleteness and we can envisage, perhaps, alternatives to a comprehensive mapping.

There is also a need for research on report-book to walk different paths from the recurrent literary approach, in a revealing movement of this good news for those who care about undergraduate education: they may be assuming buried, humanitarian assignments, linked to problem and solutions of marginalized populations, opting for a journalistic production of a more utopian character, including making strong wishes to write a book, common among Journalism students.

The confirmation of this engaged tendency could readjust the impression of those who, such as the writer and journalist Joao 
Antonio, are implacable critics of the profession. In a fundamental text entitled, Abraçado ao meu rancor (Embraced to my rancor) (2001), the author addresses the reporter's dilemmas. A confessional narrator receives assignments about tourism in São Paulo, a reason to smash journalistic frustrations. He complains of the gradual loss of freedom, of ethical commitment, of style, and, as regards to the central topic of this article, he cannot but admit, when he becomes part of the so-called middle class, his undeniable detachment, as well as that of his colleagues, in relation to the main problems of the majority of the population, working people crowding São Paulo capital's buses and trains. Disillusioned, the autobiographer-narratorreporter reaches offense peaks: Journalism "is not even a decent people's profession":

It is worse, in the country, the guy who, as a writer, becomes a journalist. There, he will lose more potential - time, shame, talent and style. In addition, of course, of running other serious risks of useless pain. Premature aging, intimate old age, impotence, fear, plus small deformations and middle class's addictions gets on him. He will hum all the time for it - and never orbit out of its reach - and delude himself, cunning and frantic, by the pubs to say, only after drinking, that he does not belong to it. It has turned to fashion, for example, the proclamation that one is a middle class marginal. Or shitty class. The second form, in a time when the game of words and the use of the word are used as a sign of talent, is more elegant. Shitty. Being able to embolden this, then, is the fine of the spirit. Updated, refreshing and progressive. It composes well. It sounds creative (Antônio, 2001, 84).

The report-book is a fertile ground for misunderstandings between Journalism and Literature, a debate that tends to be prevalent, as if the primary concern, from the point of view of production and report-book's theory, should invariably encourage demands around literary-journalistic issues. In this article, however, we adopt another bias, related to human rights assumed as a task by the Brazilian State.

If, as João Antônio describes, professional practice is undermining forces and ideals, journalism undergraduate students who opt for the report-book seem to be able to perform improbable utopias, such as being affected by causes of social and democratic appeal, exercising the pleasure of writing in long emancipatory narratives of reductionist paradigms (Medina, 2016), but also have the chance to complete the course having theorized and produced journalistic format in more detailed thesis. 
DO UNDERGRADUATE JOURNALISM STUDENTS TEND TO WRITE REPORT-BOOKS ON HUMAN RIGHTS?

\section{Methodological procedures}

Considering the research's difficulties and care, in this topic we intend to describe and justify the methodological choices for the initial indexing of the Journalism Brazilian Course Completion Works (TCCs), specifically those carried out as a report-book. Mandatory, these works are individual or in group, produced in the final undergraduation stage, in the last or the last two semesters. They are preceded by a research project addressing mandatory items such as justification, theoretical reference, objectives, methodology and timetable. In addition to formal reflection in academic language, the practical product must materialize what has been theorized. With slight variations as to the possible types in each course over Brazil, undergraduate students will be able to carry out monographs and journalistic products for radio, television, Internet and printed material such as newspaper, magazine and report-book, format that we begin to understand in this research.

TCC is a culmination moment in the journalist formation and our interest in them, for the moment, questions the essential: what kind of journalistic product does the undergraduate student choose and which topics do they prefer? As for the report-book, we also ask how much it represents in the set of formats produced and awarded.

These are three questions we asked the research sources. Regarding the TCCs, we used spreadsheets provided by the journalism course coordination of the particular researched institution, with a representative number of students allocated in two units and in different regions of the capital of São Paulo between 2015 and 2017.

In the semiannual worksheets there are data about the TCCs such as the supervisors' and mentees' names, work titles, chosen formats, besides date and presentation place. We have retained the information indicated in the triad of questions about format, topic and representativeness and the results will be presented and discussed in a later topic. For now, it is suffice to say that the reportbook is the preferred format among radio, television, virtual, print and monograph products.

In addition to the spreadsheets, which may indicate perennial preference for the report-book in the researched institution, we seek to advance the perception of the topic that we will characterize as humanitarian and then we resort to a collection of reports produced in the same institution in 2016 (Zibordi, 2016), which include texts later expanded as TCCs in report-book format. 
Despite the instigating subsidies obtained, the concern about the delineation of a possible Brazilian panorama led us to research relevant national awards for TCCs, specifically two of them, one of professional character and another academic, through which it is possible to know the diverse journalistic formats done by the undergraduate students and also select the subset that interests us, the report-book.

As in the researched private institution of São Paulo, we again asked about formats, topics and representativeness of the TCCs competing in the annual competitions of the Brazilian Association of Investigative Journalism Exhibition (Abraji) and the Experimental Research in Communication (Expocom). Prizes do not involve monetary values, but they are relevant as a distinction, especially to a trainee, who can present promising results to the market or the Academy.

Regarding the two awards, in addition to the three answers indicated in the questions, we also obtained other relevant information. Let's start with Abraji. This is a nonprofit professional association that does not receive government funding. Founded in 2002, it promotes several courses, mainly via internet, and annual face-toface international seminars aimed at the improving of journalists and students, as well as publishing reference works on research topics. Among other notable achievements, Abraji decisively pressed for the approval of the Law on Access to Information in 2011 , which allows any Brazilian citizen to request data from the public administration, an extremely valuable legal possibility for investigative journalism. In 15 years of operation, Abraji became an important association of Brazilian professionals.

Since 2014, it has awarded TCCs previously oriented and approved in public and private institutions in the monograph, audiovisual, photography, report-book-and multimedia production categories. Despite the short existence time, four awards up to 2017, the event matters to us by the national scope and for being promoted by professionals, even allowing distinguishing the report in book of the other formats. If it continues, its results may be a timeline of interest for this survey; however, the scope imposes its own restriction, especially since Abraji does not disclose information about the entries, other than their total. As for the winners, the electronic files of the productions are available. We obtained these files and extracted information to constitute a table, commented below, in which, in addition to the triad of basic questions to guide us, we indicate the work origin institution. 
As for the report-books, we will comment on two winning works, one in 2016 and another in 2017.

The other investigated award, the Experimental Research in Communication Exhibition (Expocom), did not provide digital files of the Journalism students' practical work, so we did not read them at this stage of the research, but it publishes, in its Annals, scientific articles written by the competitors in the regional and national phases - we read these finalist articles, especially to verify the humanitarian hypothesis indicated since the titles of the winning works listed in the tables of the annual awards established since 2012, which include the winners of all categories and subcategories.

In the first phase of Expocom, the educational institutions indicate the competing works. The projects are then presented at the regional meetings, which involve oral support of a scientific article. Five meetings take place annually in different regions of Brazil, culminating in a national meeting.

Students can compete in six categories with a variable number of subcategories, Journalism having 16 possible modalities, among them the report-book. The Expocom award is part of the annual meetings of the Communication Sciences Brazilian Congress (Intercom), the largest in the area in Brazil, held for 40 years, since 1977. It brings together undergraduate and graduate students and researchers in different cities each year, distributing other awards beyond what matters in this survey. In Expocom, only one work is a winner in each subcategory.

It is important to mention that we have not yet made an investment that will merit a later specific article: the analysis of all published articles and works of Expocom's competitors in the reportbook category since 2012 , presented in regional and national phases. This analytical investment will certainly confirm or refute our premise about the humanitarian bias of the works, including with regard to the bibliography mobilized by undergraduate students. For now, we have listed Expocom's long-running journalistic narratives in which we will make initial considerations in a later section.

\section{Report-book and human rights}

Understanding the report-book as a journalistic product capable of overcoming the limitations of daily press coverage 
presupposes that the breath narrative can advance the "deepening of our time knowledge, eliminating, in part, the ephemeral aspect of the current message practiced by daily channels of journalistic information" (Lima, 2009, p.4).

According to Lima, the report-book should both extend and verticalize the approach - in the horizontal extent are the quantifications (numerical surveys, for example), while in the vertical, intensive, there is qualitative information:

\begin{abstract}
At best, the report-book is presented with an equally extensive and intensive depth. In the first case, the number and quality of the details enrich the narrative for an information degree ideally superior to that of everyday vehicles. In the second, verticalization solidifies the real understanding of the topic and its precise insertion in the contemporary context (Lima, 2009: 40).
\end{abstract}

In order to meet these assumptions, the report-book expands the limits of the common procedures for journalism capturing, writing and publishing, starting with the topic, which should not be restricted to the issues foreseen by historically established publishers such as politics, economics, sports, and daily news - and even if the subject is framed in any of them, the results will differ in depth coverage.

In that sense, if we can confirm the trend towards humanitarian assignments in journalism undergraduate students' report-books, we can safely demonstrate a fundamental divergence in relation to the daily news coverage, which historically disregards such approaches.

If the subject of the report-book is, in the limit, any one of human interest, the long journalistic narrative in book is not based, in principle, by occurrences reported by the daily news editorials, printed or virtual, but by historical events of greater duration, except when the most current fact justifies immediate beginning of in-depth investigation, even before the final contours of the plot are defined.

Assignment execution presupposes, among other requirements, the activation of the senses and perceptions, "seeing" instead of mere "looking", sharpening the ears to better dialogue, preferably with much more sources than the commonly authorized ones. Information gathering procedures should be more ambitious and complex, close to scientific ones, avoiding common limitations, such as in field trips. As Lima quips, "if the programmed question and answer scheme is not applicable, the reporter thinks that he is not faced with a journalistic fact" (2009, p.90).

Observations can be intense, time consuming, participating. 
And, regarding the interviews, they presuppose a specific sense of humanization, according to Cremilda Medina (1995). For her, the ideal word for naming the journalistic procedure would not properly be "interview", but "dialogue", as ambitious as possible, fluent, parity and open. If dialogue occurs, it is no longer the relationship between subject and object (or objectified interviewee), but rather the encounter between subjects willing to listen and learn, reciprocally.

\begin{abstract}
The narrative then oscillates between the scene of the event and the world of measurable objective ideas and data. The analytical reason expands the technical performance impelled by the sensible experience of the contact, of the field trip and the fact of being affected to human happening. Solidarity ethic lubricates the technique, which is expressed in an original action, that of the Authorship of the collective signature. (Medina, 2010, pp. 152-153).
\end{abstract}

In addition to the broad possibilities of thematic, assignments and processes of information gathering for the report-book, from the textual point of view, the choices are copyrighted, from the general frame of the narrative, for example, being linear or not, until the construction of unusual narrators and the adoption of a writing deviant from the normative standard, emancipated from the already characterized "linguistic prejudice" (Bagno, 2007).

With this minimal indication of how we subsidized our understanding of the report-book, we referred to the first half of Edvaldo Pereira Lima's work on the expanded journalistic process; the second part deals with literary relations, unfolding that we are not interested in this article.

Our central axis of discussion, as we are demarcating, are the humanitarian assignments in the report-books produced by Journalism undergraduate students. That is why it is important to situate them as we understand them: when we speak of the currently debated "human rights", we first have in mind the Universal Declaration of Human Rights ${ }^{3}$ and the Brazilian Journalists' Code of Ethics ${ }^{4}$ - the first document guarantees minimal dignity for every human being, indispensable rights such as security, health, education, work and. freedom of expression. The Code of Ethics, in turn, establishes the journalist's duty "to oppose arbitrariness, authoritarianism and oppression, as well as uphold the principles expressed in the Universal Declaration of Human Rights."

In adopting a legal-political perspective on human rights, we believe that it is consistent not only with the interests of this article, 
but also with the establishment of legal parameters of humanitarian character in Brazil, whose recent trajectory can be defined by the violation of these same rights during the military dictatorship between 1964 and 1984, and its subsequent slow and problematic implementation by government agencies in the last thirty years of redemocratization (Vieira, 2005; Adorno; 2010; Engelmann; Madeira, 2015). Thus, if the progress of this research can verify that the long journalistic narratives produced by journalism undergraduate students report topics of humanitarian interest, or at least those protected by law, they would not only expand the coverage of the subject in relation to the daily press, but also express harmony with the most current paradigms gradually assumed by the Brazilian State, where all the difficulties and justifiable criticisms regarding the legislation are not always applied.

As Brito (2013) reminds us, such rights depend much more on their recognition by the States than the UN Universal Declaration of Human Rights does. In Brazil, according to Engelmman and Madeira (2015), in the last half century we have moved between the suppression of human rights and difficult institutional adoption. Their defense inevitably led to a confrontation with the Dictatorship, which suspended the legal and political order, highlighting, among others, lawyers' activism linked to the Catholic Church sectors. The later confluence, in the $80 \mathrm{~s}$, generates claims that will result in bureaucratic structures, state or not, but with a tendency to articulate, and in the diversification of the human rights assignments.

During the Dictatorship, the creation of the Justice and Peace Commission in 1969 "affirms itself as one of the milestones in the articulation of the human rights cause in Brazil" (Engelmann; Madeira, 2015). Connected to the Catholic Church, the Commission founded a nucleus for the defense of political prisoners with lawyers whose performance is relevant to the institutionalization of human rights in Brazil, having judicially and publicly challenged the military regime, published doctrines and acted to guarantee humanitarian devices in the Constitution of 1988. "They also occupied important public posts in the 1990s, when bureaucratic structures that promote human rights cause as a" State cause" (p. 626) begin to be built.

Progress has been gradual, but it is notable that in 1982, even during the military regime, the Human Rights National Movement was founded. However, as the authors have pointed out, "the institutionalization process does not imply social legitimation at 
the same pace" (p. 627), and the Movement has faced dilemmas in the last decades, some of them from the relationship with the State (Vieira, 2005).

The important institutional step that interests us in this research is the editing of the First National Human Rights Plan (PNDH, in the Portuguese acronym) in 1994 and the creation of the National Human Rights Secretariat, linked to the Ministry of Justice and charged with executing the PNDH. In the first and second (2002) and third (2009) national plans, the Brazilian State recognizes its obligation to promote human rights.

Aiming at relations with the report-books' topics, in relation to the 1994 I PNDH's forecasts, we highlight the transfer of the military police officers' trial to the common justice, the definition of the crime of torture and the creation of the Refugee Statute.

The II PNDH, with 518 measures, incorporated and amplified criticisms made to the previous Plan. Rights related to free sexual orientation and gender identity, gypsies protection, fight against child labor, reinforcement of measures against family violence and attention to people with special needs were guaranteed. And, fundamental in its confluence with the report-books' topics, the Afrodescendants' rights are guaranteed.

The III PNDH of 2009, the longest of them, resulted from demands from 50 thematic conferences held since 2003, in which 1,200 delegates and 800 observers and guests were elected. The measures envisaged that interest us in the relationship with the assignments of the undergraduate students report-books authors have generated media controversies, such as the proposal to create a National Truth Commission, abortion decriminalization, civil union between same sexes, adoption of mediation mechanisms in urban and rural conflicts, media control.

According to Adorno (2010), the three editions incorporate a "new conception of human rights", in line with the 1993 World Conference, recognizing "the indivisibility of human rights: human rights are not only civil and political rights but also economic, social, cultural and collective rights, which is a great novelty in the social history and republican politics in Brazil" (p.11).

These difficulties - whose distorted and popularized epithet is "human rights are rights to protect thugs" - make us think on the report-book productions of the journalism undergraduate students that play an important role in legitimizing humanitarian assignments. 
Despite the current relevance of the topic, the Brazilian press still produces pernicious journalistic programs; see the televisions in José Luiz Datena's style and his Brasil Urgente. In these coverages, the whole fragile notion of human rights that is still being built in Brazil is literally bombarded.

On the other hand, as this research intuits and intends to confirm, Journalism undergraduate students seem to opt precisely for producing report-books focusing on topics related to human rights, almost all of which can be found in the three National Plans mentioned above.

Let us try, in the next topic, a small understanding step: to cross the award results for journalism undergraduate students, authors of report-books, with the their production in a University Center in the capital of São Paulo seeking answers to the three initial questions that move this research: which types, topics and the representativeness of the long journalistic narrative in book.

\section{Under graduate students taking causes?}

As we have stated, we have collected information on Journalism TCCs in a private institution, researched in the state capital between 2015 and 2017. The semiannual worksheet data, we said, are quite complete. With this wealth of information, which unfortunately is not always available, these worksheets should be revisited. So far, we have done a small data extraction, based on the three axes that interest us.

When we add up the total number of projects and subtract from the set the number of report-books, we see the preference for the long journalistic narrative in book, an indicator that to be admitted as a trend needs to be verified for a longer time not only in the researched institution, but especially in other courses from the same city and also from different regions of the country, public and private, possibly crossing productions, as we are proposing, with the award results from professional and scientific associations. In an increasingly virtual environment, it may be astonishing to note the preference for books, especially if we can have some assurance about the thematic trend.

In the researched institution, we found that the report-books represent $42 \%$ of the undergraduate students' productions between 
2015 and 2017. The rest are radio, audiovisual, multimedia, printed and monographic works. The percentage represents 174 books in a universe of 409 works.

Table 1 -TCCs production at FIAM FAAM

\begin{tabular}{|l|l|l|l|}
\hline & $\begin{array}{c}\text { REPORT- } \\
\text { BOOKS }\end{array}$ & $\begin{array}{c}\text { OTHER } \\
\text { FORMATS }\end{array}$ & TOTAL \\
\hline $\mathbf{2 0 1 5 - 1}$ & 07 & 19 & 26 \\
\hline $\mathbf{2 0 1 5 - 2}$ & 42 & 49 & 91 \\
\hline $\mathbf{2 0 1 6 - 1}$ & 12 & 24 & 36 \\
\hline $\mathbf{2 0 1 6 - 2}$ & 44 & 63 & 107 \\
\hline $\mathbf{2 0 1 7 - 1}$ & 29 & 29 & 58 \\
\hline $\mathbf{2 0 1 7 - 2}$ & 40 & 51 & 91 \\
\hline & $\mathbf{1 7 4}$ & $\mathbf{2 3 5}$ & $\mathbf{4 0 9}$ \\
\hline & $\mathbf{4 2 \%}$ & & \\
\hline
\end{tabular}

Source: Spreadsheets provided by the coordination.

These work assignments are suggested by students and teachers, who begin to develop the theoretical project in the penultimate graduation semester, making the report-book in the latter. The general topic ends up being, in most cases, some of the main demands foreseen in the national human rights plans such as racism, sexuality prejudice, economic, educational, work and public transportation problems, based largely on the students' profile, several of them from the outskirts of the capital of São Paulo and surrounding cities.

Exemplary of the thematic trend of verifiable social appeal in the products developed at the researched institution is the undergraduate students' first collection of texts, published in 2016, with reports aimed at enabling them to write the report-book in the last semester. The series entitled Textos para livro-reportagem (Texts for report-book) (Zibordi, 2016) deals with missing children and transgender children, street pregnant women, street vendors, women's aggression, journalism in the outskirts, Haitians', Lebanese's and foreign prisoners' lives in Brazil, linguistic prejudice in the daily life of the poor, the murder of MC Daleste, a funk singer from the eastern part of the state capital, and other related assignments.

Also in 2016, a report-book produced the previous year at the 
researched institution, whose embryonic report was included in the collection above, was one of the Abraji award's winners, one of the institutions whose awards we have chosen for this research. Jennifer Vargas Rodrigues reported the bloody history of more than 500 deaths in São Paulo after the 2006 attacks promoted by the First Command of the Capital (PCC). Almost a decade later, when little progress had been made in solving the case, the report-book was presented along with three other award-winning papers of the same journalistic nature at the 11 th International Congress of Investigative Journalism of the Brazilian Association of Investigative Journalism (Abraji). ${ }^{5}$

The book recounts the "May crimes," referring to the month in which hundreds of innocents died in slaughter at the hands of hooded suspects. It also updates the assignments by narrating the relatives' battle for justice and interviewing, especially, women organized in groups of mothers, wives, relatives and friends close to the victims. In the same event, the other selected works point back to the human rights assignments: one of the report-books on children housed by the State (Souza, 2015) and crack-land in Belo Horizonte (Ferreira, 2015).

Abraji data are included in our research since 2014, when the Association instituted the TCC award. Students can submit projects presented to their educational institutions in the previous year. Four works are chosen annually, with the exception of 2016, with six.

As shown in the following table, two trends may be taking shape regarding the format and selected product thematic for presentation at Abraji annual congresses: the report-book format and its respective humanitarian assignments. Commenting on the chosen ones of 2015 , the Association states that "in different ways, everyone approaches the human rights assignments". ${ }^{6}$

In addition to Abraji's first four awards, the report-book accounts for two-thirds, or 12 out of 18 works. This data should be qualified considering the consonance between the long journalistic narrative in book and Abraji's objectives, since the in-depth research serves both the type of journalism promoted by the Association and the assumptions of the report-book. However, data relevance on the Abraji prize is not necessarily in the quantity of works neither evaluated nor awarded, but in the geographical scope of the contest.

Without disregarding these and other complexities, we believe that this award comes together and may even broaden our premise that the Journalism undergraduate students' report-book assignments seek to hear the appeals and understand the historically 
buried characters and facts. The 2017 awards selected, among four works, two books, one of them being about the musical culture of the mods, originally British, with unfolding almost unknown in São Paulo's scene. In André Carmona's book (2016), those previously ignored by the journalistic narrative were musicians and fans - although, as the author informs us, in a 1985 album, the São Paulo band Ira!, in the last song on the $B$ side, protest that nobody understands a mod ...

Carmona's work recaptures the British scene and, above all, São Paulo scene, both strongly identified with its music, leading the reader to understand that there was much more than the Beatles, tropicalism, the "rock of the eighties." This is from the point of view of the assignments, which broadens the perspective of the daily press approach, as advocated by Edvaldo Pereira Lima (2009).

As for capture procedures, the interview with the trio of members of the extinct band Faces e Fases makes the effort to listen and make the musicians, now separated, dialogue. The band is the first mod of Brazil formed "by three young people from the outskirts with somewhat unusual tastes who intend to assemble the equipment to play on the house's slab" (Carmona, 2016, 39).

After interviewing the musicians separately, the author edited the answers at the points where the respondents deal with the same subjects. The rearranged speeches are identified with images of the instruments played by each of the musicians, small icons inserted on the sides of the 45 pages dedicated to the interview, which orchestrates three voices (pp. 44-85).

The visual appeal of these minimal images and photos interspersed with the pages advances reading and creates visual sighs to the textual mass. From the point of view of report-book theory, the work promotes "fruition by the text" (Lima, 2009, 134), so that the plurality of voices is conjugated to the plurality of meanings, making the work polyphonic and polysemic, as befits narrators who are attached to democratic ideals (Medina, 1995, 2014).

The work on rock and the report-book on the murders in São Paulo size how much the award reinforces the perspective that the long journalistic narrative conducted by Journalism undergraduate students may be tending to humanitarian subjects. In the following table, with Abraji awards, only the reading of the titles, even those shortened to enable visualization, will indicate the reader the possibility of thematic convergence to be national, independent of the region and the type of institution. 
Table 2 - Abraji awards 2014-2017

\begin{tabular}{|c|c|c|}
\hline 2014 & FORMAT & INSTITUTION \\
\hline Women in prison & Report-book & UNEB \\
\hline $\begin{array}{l}\text { Lead carpet: the silenced story of } \\
\text { the Brazilian city with the highest } \\
\text { contamination ... }\end{array}$ & Report-book & USP \\
\hline $\begin{array}{l}\text { The Xavante saga and the (dis) ways } \\
\text { of reporting: cultural symbolism in the } \\
\text { struggle... }\end{array}$ & Report-book & UFMT \\
\hline $\begin{array}{l}\text { "Gay Cure": For almost } 30 \text { years, Brazilian } \\
\text { medicine was making a pioneering } \\
\text { decision that ... }\end{array}$ & Report-book & USP \\
\hline \multicolumn{3}{|l|}{2015} \\
\hline $\begin{array}{l}\text { June } 13 \text { - Stories of a War Night in São } \\
\text { Paulo }\end{array}$ & Report-book & Methodist (SP) \\
\hline Encantada women & Report-book & UFC \\
\hline $\begin{array}{l}\text { The prisons' scream: watched today, } \\
\text { punished forever }\end{array}$ & Report-book & PUC-GO \\
\hline $\begin{array}{l}\text { Silenced: violence against journalists in } \\
\text { Brazil }\end{array}$ & Multimedia & $\begin{array}{l}\text { Anhembi- } \\
\text { Morumbi }\end{array}$ \\
\hline \multicolumn{3}{|l|}{2016} \\
\hline State child & Report-book & Unasp \\
\hline $\begin{array}{l}\text { May } 2006 \text { Crimes - The } 500+\text { killings } \\
\text { retaliate against PCC's attacks ... }\end{array}$ & Report-book & FIAM FAAM \\
\hline $\begin{array}{l}\ldots \text { that ignites the first stone. Belo } \\
\text { Horizonte's crack-land ecos }\end{array}$ & Report-book & UFMG \\
\hline $\begin{array}{l}\text { Pulpit and Parliament: Evangelicals in } \\
\text { Politics }\end{array}$ & Documentary & PUC-SP \\
\hline Dodge - Public Policy Journalism Agency & $\begin{array}{l}\text { Online } \\
\text { Agency }\end{array}$ & Methodist (SP) \\
\hline Musical Realities & Comics & UFSJ Del-Rei \\
\hline \multicolumn{3}{|l|}{2017} \\
\hline $\begin{array}{l}\text { Mods: a São Paulo's underground } \\
\text { phenomenon }\end{array}$ & Report-book & FIAM FAAM \\
\hline Between Veils and Voices & Report-book & Cásper Líbero \\
\hline $\begin{array}{l}\text { Data Journalism and Brazil elections } \\
\text { coverage }\end{array}$ & Monograph & ESPM-RJ \\
\hline $\begin{array}{l}\text { Brazil women's magazine market: from } \\
\text { the Mirror AZMina }\end{array}$ & Monograph & UNIP \\
\hline
\end{tabular}

Source: Abraji site. 
Regarding the results of the Experimental Research in Communication Exposition (Expocom), considering the winners in the report-book category between 2012 and 2016, it is again possible to glimpse the national scope of the option for humanitarian assignments in works developed in public and private courses. ${ }^{7}$ That is, there is a possible thematic agreement among those awarded by Abraji and Expocom.

We are giving, we know, the first steps, but, from the following table, we will verify that the humanitarian assignments reappear in a larger Expocom universe of winning works in report-books.

Expocom began by awarding in 2012 a long journalistic narrative about the samba singer Clementina de Jesus, written because of the "great incidence of people who do not know the artist" (Castro; Costa; Kobayashi; Marquesini; Munhoz, 2012). The following year, a similar topic was based on the award-winning book (Freitas; Santos; Silva, 2013), a work that traces Edésio Santos's profile, a musician and cultural agitator fundamental to Juazeiro (BA). Unpretentious Bohemian, he lived between 1931 and 1998, having been a shoeshine, a bricklayer's helper, a watchmaker and a civil servant. The authors manifest intention is to recover the trajectory of someone who, without national visibility, ran the risk of not having substantial journalistic record about his life.

The basis of the narrative is 38 interviews and the article of the winning authors mentions as a theoretical basis for the journalistic practice the proposals of humanized dialogue by Cremilda Medina (1995). The propositions of this author quoted a few times in this article are related, for the undergraduate students and for this author, especially, to his work on interview as possible dialogue.

And there is a precise sense of how this relationship between interviewer and interviewee should occur. The possibility of dialogue exists not only by their topic mastery, nor is it guaranteed by the rigid technique of previous questionnaires, or even in the declarant's long transcripts, but it can spring in the "being affection" to the other without any subservience or dazzle. According to Medina, this is an indispensable condition for any pretension to give voice to the other and to his or her causes - an attempt with great possibilities of not going beyond pretension.

Rather than rationally understanding theoretical proposals, the articles of the award-winning authors overflow with complicity with the task asignment that, as we have characterized, is in line 
with humanitarian issues assumed by the Brazilian State. In their interviews, young journalists claim to have sought the "building of a humanized relationship" (Freitas et al., 2013).

"Being affectionate" still beacons the award-winning reportbook in 2014 . Written by three authors, it tells the daily lives of four inmates of Ceará's only female prison. In the work, we again identify the theoretical consonance with Cremilda Medina. When it comes to the "art of weaving the present" (2003), that is, of constructing contemporaneity journalistic narratives, Medina identifies in the narrators' creation, a real possibility of reporting in line with contemporary paradigms, such as those related to human rights. It is not a question of speaking for the other, but with the other, as do the authors of Auri, a anfitriã (Auri, the hostess), the name of the narrative voice constructed from the testimonies of the four inmates. The authors demonstrate a great deal of awareness about this leading voice:

The narration goes far beyond a literary technique. It works as the contribution of objectivity, because the narrator, as well as its creators, tells what they heard from their characters. It represents, at the same time, the subjectivity and objectivity of the journalists who speak through it. (Fernandes; Moura; Pereira, 2016).

This statement also corroborates with Lima's perspective (2009), for whom the report-book expands the limits of daily journalistic coverage. With the same intention, the work awarded by Expocom in 2015 sought to understand the conflicts in Ethiopia, Sudan, South Sudan and Uganda, rarely reported, usually in extreme moments. In the corresponding scientific article, we read that before the interviewees "it began with an unpretentious conversation, without blocks, only with great eagerness to know stories" (Paula; Sá, 2015).

In 2016, in the last award prior to the writing of this article, the selected work reported depression from research on how people can represent a time. According to theorists, "the report-book assumes a significant role in story preservation and transmission, dormant in contemporary society, on the margins of the stories, produced by the great media". (Faria; Franco; Gonçalves; Leal, 2016).

The narrative brings accounts of those who take medicine, those who seek to stop taking, pain and victory trajectories in dealing with the disease, examples of overcoming and mutual help, and expert opinion. As the Abraji award-winning report-book on São 
Paulo rock, Expocom's selected work on depression broadens the notions of exclusion and marginality beyond socioeconomics, as it engages in issues related to art and health.

Table 3 -Prizes for report-books in Expocom

\begin{tabular}{|c|c|}
\hline TITLE/AUTHOR & INSTITUTION \\
\hline \multicolumn{2}{|l|}{2012} \\
\hline $\begin{array}{l}\text { Quelé: the voice of the color, Clementina de } \\
\text { Jesus's work and legacy, by Janaina Marquesini } \\
\text { Borges Abicair. }\end{array}$ & Methodist (SP) \\
\hline \multicolumn{2}{|l|}{2013} \\
\hline $\begin{array}{l}\text { Slow walk - Stories and Songs by Edésio Santos, } \\
\text { Edilane Ferreira da Silva. }\end{array}$ & UNEB \\
\hline \multicolumn{2}{|l|}{2014} \\
\hline $\begin{array}{l}\text { Auri, the hostess: memoirs of the Women's } \\
\text { Criminal Institute Officer Auri Moura Costa, by } \\
\text { Aline de Sousa Moura. }\end{array}$ & UFC \\
\hline \multicolumn{2}{|l|}{2015} \\
\hline $\begin{array}{l}\text { We are here - Stories of conflict victims in East } \\
\text { Africa, by Jéssica Paula Prego. }\end{array}$ & UNB \\
\hline \multicolumn{2}{|l|}{2016} \\
\hline $\begin{array}{l}\text { Unshaded eyes: testimonials of those who see } \\
\text { the depression, by Cristiano Eduardo Faria. }\end{array}$ & UBC \\
\hline
\end{tabular}

Source: Expocom site.

In this context of academic productions and promotional awards of report-book based on topics directly related to human rights, we cannot go very far, for now, and generalize. Many questions still need to be answered.

\section{Possible conclusions}

The main question is whether the trend presented here can be confirmed, and how, considering that in the increase of the research, new methodological procedures should be adopted, such as a virtual electronic platform with information from various sources (teaching 
institutions and awards, especially) for crossing data and attempts to advance to possible answers to fundamental questions.

Some of them: does the preference of undergraduate students for the report-book have any correlation with the type of higher education institution, public or private? What about the students' socioeconomic profile? And with the region where the course is located? What is the percentage of long journalistic narratives in book in relation to other types of TCCs? How is the distribution of these productions at least in São Paulo and Metropolitan Region, which concentrates most of the Journalism under graduation degrees in the country? Do the trainees take the same demands on professional life? Is it possible and necessary to subdivide humanitarian assignments addressed in report-books into specific categories such as art and health, as we have done in this article? What about the types of reportbooks, what would be the theoretical gain in categorizing productions?

With regard to the latter question, regarding the possible typologies, we could subsidize the re-discussion of Lima categorizations (2009, pp. 51-59), author that indicates 13 types of report-books, but develops little or no conceptualization of them. We ask, for example, if the tendency to "testimony-report-book" (p.52) stems from the relative ease of collecting and publishing interviews, or whether the tendency to contemporary topics can resize the "instant-report-book" (p. 57).

In the this research's next updating article we intend to have advanced in the answers to some of these questions derived from the basic question, about the long journalistic narrative in book produced by undergraduate students tends to human rights.

*This paper was translated y Audrey Frischknecht

\section{NOTES}

1 The first version of this article was presented at the 14th Researchers' National Meeting in Journalism (SBPJor), held in Santa Catarina, in 2016. In the same year, it was republished as an introduction to the first volume of the texts collection report-books, which brings together undergraduate students' production candidates to write the long narrative in book. In this version, we practically rewrote all of the text and updated the data about the course completion work of the students of the researched institution in the capital of 
São Paulo until the end of 2017, since in April of the same year the products, topics and counselors of the trainees were defined. Thus, we have advanced three semesters in relation to the information collected in the first version of this article.

2 The number of students was provided by the FIAM FAAM - Centro Universitário. In addition to the undergraduate degree, the institution has maintained the Professional Master's in Journalism since 2015 , from which we began to collect information about the practical and theoretical work of the undergraduate students.

3 Retrieved from www.onu.org.br/img/2014/09/DUDH.pdf.

4 Retrieved from fenaj.web2015.uni5.net/wp-content/uploads/201 4/06/codigo_de_etica_dos_jornalistas_brasileiros..pdf.

5 Retrieved from www.abraji.org.br/?id=90\&id_noticia $=3433$

6 Retrieved from http://www.abraji.org.br/home?id=90\&id_noti$\mathrm{cia}=3065$

7 Retrieved from http://www.portalintercom.org.br/premios_new/ expocom/apresentacaol 1 .

\section{REFERENCES}

Adorno, S. (2010). História e desventura: o $3^{\circ}$ Programa Nacional de Direitos Humanos. Novos estudos - CEBRAP. 86, 05-20.

Antônio, J. (2001). Abraçado ao meu Rancor. São Paulo: Cosac \& Naify Edições.

Bagno, M. (2007). Preconceito Linguístico: o que é, como se faz. São Paulo: Loyola.

Besson, Jean-Louis. (Org.). (1995). A Ilusão das Estatísticas (Sader, Emir, Trad.). São Paulo: Editora da Universidade Estadual Paulista.

Brito, F. (2013). A ruptura dos direitos humanos na filosofia política de Hannah Arendt. Kriterion: revista da Filosofia, 54 (127), 177-196.

Carmona, A. Nós Somos os Mods: um fenômeno tipicamente britânico na cena underground paulistana. (2016). São Paulo: Editora Casa Flutuante.

Castro, F., Costa, L., Kobayashi, M., Marquesini, J., \& Munhoz, 
R.. Quelé: a voz da cor - obra e legado de Clementina de Jesus. (2012, September). Anais do Congresso Brasileiro de Ciências da Comunicação, Fortaleza, CE, Brasil, 35.

Descartes, R. (2001). Discurso do método. (Ermantina, Maria, Trad.). São Paulo: Martins Fontes, 2001.

Engelmann, F., Madeira, L. M. (2015). A causa e as políticas de direitos humanos no Brasil. Caderno CRH. 28 (75), 623-637.

Faria, Cristiano E., Franco, Cauê M. L., Gonçalves, Lucimar, \& Leal, Lia (2016, setembro). Qual o papel do livro-reportagem na descoberta de pessoas que representam uma época?. Anais do Congresso Brasileiro de Ciências da Comunicação, Rio de Janeiro, RJ, Brasil, 39. Retrieved from http:// portalintercom.org.br/anais/nacional2016/expocom/EX53-0237-1.pdf

Fernandes, K. B., Moura, A. S., \& Pereira, B. A. (2014, September). Auri, a anfitriã: memórias do Instituto Penal Feminino Desembargadora Auri Moura Costa. Anais do Congresso Brasileiro de Ciências da Comunicação, Foz do Iguaçu, PR, Brasil, 37.

Ferreira, L. G. A. (2015). ...que acenda a primeira pedra. Ecos da Cracolândia de Belo Horizonte. 2015. Journalism end-of-course written paper, Universidade Federal de Minas Gerais (UFMG), Belo Horizonte, MG, Brasil.

Freitas, R. C. S. B., Santos, E. C. V., \& Silva, E. F. (2013, setembro). Lento caminhar - histórias e canções de Edésio Santos. Anais do Congresso Brasileiro de Ciências da Comunicação, Manaus, AM, Brasil, 36.

Lima, E. P. (2009). Páginas Ampliadas: o livro-reportagem como extensão do jornalismo e da literatura (Ed. rev.). Barueri: Manole.

Medina, C. (1994). Sob o signo do diálogo - relato de experiência: projeto São Paulo de Perfil. Comunicação e Educação, 01(1), 93-104.

Medina, C. (1995). Entrevista: O Diálogo Possível. São Paulo: Ática.

Medina, C. (2003). A Arte de Tecer o Presente: narrativa e cotidiano (2003). São Paulo: Summus.

Medina, C. (2008). Ciência e Jornalismo: da herança positivista ao diálogo dos afetos. São Paulo: Summus.

Medina, C. (2010). O criador da assinatura coletiva. In Medina, C. (Ed.). Liberdade de Expressão, Direito à Informação nas Sociedades Latino-americanas (pp. 145-155). Série Novo Pacto da Ciência (Vol., 11). São Paulo: Fundação Memorial da América Latina.

Medina, C. (2014). Narrativas da contemporaneidade: epistemologia do diálogo social. Tríade: comunicação, cultura e mídia, 02 (04), 8-22. 
Morin, E. (2010). A Cabeça Bem-feita: repensar a reforma, reformar o pensamento (Jacobina, Eloá, Trad.). Rio de Janeiro: Bertrand Brasil.

Paula, J., \& Sá, S. (2015, setembro). Estamos aqui: histórias das vítimas de conflito no leste africano. Anais do Congresso Brasileiro de Ciências da Comunicação, Rio de Janeiro, RJ, Brasil. Retrieved from http://www.portalintercom.org.br/anais/centrooeste2015/ expocom/EX46-0239-1.pdf

Rodrigues, J. V. (2015). Crimes de maio de 2006: as + de 500 mortes no revide aos ataques do PCC em São Paulo. São Paulo: Editora Casa Flutuante.

Santana, A. S. A. L. (2009). Sentidos da Metrópole: série São Paulo de Perfil na mediação do espaço público. Master thesis, Universidade de São Paulo (USP), Escola de Comunicações e Artes (ECA), São Paulo, SP, Brasil.

Souza, I. P. S. (2015). Filho do Estado. Journalism end-of-course written paper, São Paulo, Centro Universitário Adventista de São Paulo (Unasp), São Paulo, SP, Brasil

Vieira, J. C. (2005). Democracia e Direitos Humanos no Brasil. São Paulo: Loyola.

Thiollent, M. (org). (1987). Crítica Metodológica, Investigação Social e Enquete Operária. São Paulo: Polis.

Zibordi, Marcos (org.). (2016). Textos para Livro-reportagem. São Paulo: Editora Casa Flutuante.

Marcos Antônio Zibordi. Journalist, professor and researcher interested in report-book format. Undergraduate degree in Journalism from Universidade Estadual Paulista (Unesp), Master's degree in Literary Studies (UFPR) and Doctorate in Communication Sciences (ECA-USP). He has guided more than 70 report-book TCCs. He acts in UOL monitoring and criticism.

E-mailmzibordi@hotmail.com

RECEIVED ON: 30/04/2017 | APPROVED ON: 20/08/2017 